\title{
KOVACS ISTVAN
}

\section{A reglementációs prostitúció és az emberi méltóság kapcsolata, különös tekintettel egy alkotmánybírósági határozatra}

Egy ország életében az alkotmány megalkotása kiemelkedő fontosságú és nagy jelentőségü feladat. Az alkotmány - alaptörvény - egyrészt rendelkezik az alapjogok rögzítéséröl, másrészt pedig - egyebek között - biztosítja a demokráciához füződő megtartási és érvényesülési garanciát. Mivel az alkotmány normaszövege évekre, évtizedekre szól, így a megalkotásakor a jogalkotónak garantálnia kell, hogy a rendelkezések időtállók és stabilak legyenek, azokhoz kétség ne férhessen.

A törvényt úgy kell megalkotni, hogy a normaszöveg alapján a laikus számára is érthetővé váljon, hogy a jogszabály olyan értékeket állapít meg és objektívként ismer el, amelyek a közjó részeként a közösséget, az egyént és a társadalom érdekét szolgálják. ${ }^{1}$ De facto az alkotmányban megfogalmazott „természetes”, „veleszületett” és „elidegeníthetetlen” jogok nem csupán az egyén szuverén jogosultságai, hanem a közösségben élő személy közösséghez való viszonyának kapcsolatát is tükrözik.

Ahhoz, hogy ezek a jogosultságok érvényesülhessenek, és ne csak az egyén, hanem a közösség érdekét is szolgálják, ezek a jogok bizonyos mértékig a társadalom érdekében korlátozhatók. A korlátozás nem járhat mások jogának és szabadságának aránytalan sérelmével, miközben bizonyos közösségi érdekek befolyásolhatják a norma érvényesülését. Az alkotmány megalkotása garanciális szempont annak érvényesítésére, hogy - mások jogainak védelmén túl meghatározza azokat a célokat, amelyek miatt egyes alapjogok korlátozás alá eshetnek. E szabályok egyebek között a társadalmi együttélés alapjainak rögzítése, az állam és egyén viszonyának (felelősség és szabadság) meghatározása.

Eme alapjog-korlátozás alkotmányi szabályai ,vezetik át” az egyént a közösségbe, e ponton egyeztethetők össze a társadalmi szempontok ez egyén

\footnotetext{
1 Fülöp Sándor: A jövő nemzedékek országgyülési biztosának javaslatai - az új alkotmány koncepciójának kidolgozásához. Budapest, 2010. szeptember 30

http://www.jno.hu/hu/?\&menu=aktualis\&doc=alkotmany-1001

2 Az alapjogi szabályozás általános jellemzői, az alapjogok korlátozása. „Emberi jogi képzés a visszatérés területén”. Emberi Jogi képzés Projekt. Országos Bírósági Hivatal, Budapest, 2012-2013.
} 
érdekeivel. ${ }^{2}$ Különösképpen igaz ez az ember veleszületett méltóságával kapcsolatos alapjogára. Ez az alapjogosultság szoros összefüggésben áll mind a közösség, mind az egyén szabadságához és boldogulásához való jogával. Az emberi méltósághoz való alapjog a történelem folyamán sokszor került veszélybe. Jó példa erre az emberi jogok fejlódése, amely mára már a harmadik-negyedik generációját éli. ${ }^{3}$ Magyarország szintén nagy fejlődésen ment keresztül. Az 1989. évi XXXI. törvény a Magyar Köztársaság Alkotmányának módosításáról ${ }^{4}$ - figyelemmel az Alkotmánybíróság által lefektetett alkotmányos alapelvekre és alkotmányértelmezésekre - nemzetközi mérföldkőnek bizonyult, hiszen iránymutató és azóta több külföldi alkotmányreform során követett módon emelt alkotmányba harmadik generációs jogokat is.

Tanulmányomban a prostitúcióval kapcsolatos egészségügyi kiskönyv emberi méltóságot sértő rendelkezéseit vizsgálom, különös tekintettel az Alkotmánybíróság által hozott döntés ${ }^{5}$ és az akkor hatályban lévő alkotmány rendelkezései alapján. Hipotézisem szerint az egészségügyi kiskönyvben szereplö ,prostituált” kifejezés normasértő, az ellentétben áll az emberi méltóság védelmével. Magyarország Alaptörvénye ${ }^{6}$ a korábbi alkotmánytól eltéröen nagyobb súlyt fektet az emberi jogok érvényesülésére.

\section{Alkotmány és szabályozott emberi jogok}

Az alkotmány napjainkban különleges törvényt jelent, olyan alaptörvényt, amelyben az állam önmagát korlátozva szavatolja a polgárai számára az alapvető jogokat, megszabja a hatalom gyakorlásának szervezetét és kereteit. Az ilyen értelmű alkotmány a polgári fejlődés eredménye. Az alkotmány politikai megközelítésben a társadalom és a közhatalom viszonyát fejezi ki, megállapítja a hatalom korlátait és az állampolgárok szabadságjogait. Az alkotmánnyal szemben támasztott alapvető követelmény, hogy a jogokat ne csak megfogalmazza, hanem teremtse meg érvényesülésük garanciáit is.

Az alkotmány jogi megközelítésben a legmagasabb szintü norma, mert magát az alkotmányozó törvényalkotót is köti. Az alkotmány alaptörvény,

3 Csink Lóránt: Alkotmányjog. Novissima Kiadó, Budapest, 2010, 3-18. o.

4 1989. évi XXXI. törvény a Magyar Köztársaság Alkotmányának módosításáról. Hatályba lépett: 1989. október 23 .

$5 \mathrm{Az} 1 / 2011$. (I. 14.) AB határozat kimondta, hogy: „, a prostituáltak részére kiadandó orvosi igazolásról szóló 41/1999. (IX. 8.) EüM rendelet melléklete nemzetközi szerzödésbe ütközik, ezért azt 2011. december 31-i hatállyal megsemmisiti”.

6 Magyarország Alaptörvénye. Hatályba lépett: 2012. január 1. 
mert kifejezi a társadalmi beilleszkedés alapjait, meghatározza a társadalom és az állam viszonyát, megállapítja a személyes szabadságjogokat, szabályozza az államszervezet felépítését és müködését. ${ }^{7}$ Magyarországnak 1949-ig úgynevezett íratlan, történeti alkotmánya volt. Ez az alkotmánytípus - mint például Anglia jelenlegi alkotmánya is - a történeti fejlődés különböző idöszakaiban elfogadott, különböző szintủ írott és íratlan szokásjogi szabályra épül, amelynek tehát csak egy része az úgynevezett alaptörvény (például az 1222-es Aranybulla). Az 1936-os szovjet alkotmány mintájára született meg az 1949. évi XX. törvény, amely kartális alkotmány. ${ }^{8}$ Módosításához minősített többség, vagyis az országgyülési képviselők kétharmadának szavazata szükséges.

A rendszerváltás elkerülhetetlenné tette az 1949. évi úgynevezett szocialista alkotmány teljes revízióját. 1989-ben a Nemzeti Kerekasztal tárgyalásain kialakított megállapodás alapján fogadta el a még 1985-ben megválasztott Országgyülés az alkotmánymódosításról szóló törvényjavaslatot. A jelenleg hatályos alkotmány fö kereteit kialakító, 1989. október 23-án hatályba lépő 1989. évi XXXI. törvény formailag alkotmánymódosító törvény, amely szerkezetében is követi az 1949. évi XX. törvényét. ${ }^{9}$

Tartalmát tekintve azonban a Magyar Köztársaság alkotmánya a jogállamiság és a parlamenti demokrácia követelményeire tekintettel megfogalmazott új alkotmány, amely a történelmi helyzet diktálta kompromisszum és alku okán számos belső ellentmondással és joghézaggal küszködik. A köztársasági alkotmányt azóta is több esetben módosították. Az a követelmény azonban, hogy az alkotmány egy széles társadalmi konszenzus alapján kidolgozott, hosszú távra szóló alaptörvény legyen, felveti az új egységes szerkezetü, stabil, kiegyensúlyozott alkotmány elfogadásának szükségességét. Magyarország új alkotmánya a jelenleg hatályos alaptörvény nevet viseli, amely 2012. január 1-jén lépett hatályba. A mai értelemben vett alkotmány létrejötte a polgári átalakulás terméke. Ekkor vetődött fel ugyanis az az igény, hogy az átmenet eredményeit, az államhatalom korlátait, illetve az alapvető emberi jogokat egy egységes, stabil, a többi jogszabály fölött álló jogi dokumentumba foglalják.

Az alkotmányosság, az alkotmányos állam nem egyszerúen bármilyen alkotmánnyal bíró államot jelent, hanem kizárólag olyan államot, amelynek al-

\footnotetext{
7 Papp Iván: Jogi- és államigazgatási ismeretek. FVM Képzési és Szaktanácsadási Intézet, Nyíregyháza, 2004, 1-3. o.

8 1949. évi XX. törvény, a Magyar Népköztársaság Alkotmánya. Hatályba lépett: 1949. augusztus 20.

9 Barna Attila - Horváth Attila - Máthé Gábor - Tóth Zoltán József: Magyar állam- és jogtörténet. Nemzeti Közszolgálati Egyetem, Budapest, 2014, 329-350. o.
} 
kotmánya megfelel az alkotmányos állam fogalmában foglalt speciális követelményeknek. Az alkotmányos állam követelménye két összetevőt foglal magában. Egyrészről kifejezi azokat a legfontosabb társadalmi értékeket, amelyeknek rögzítését egy adott időszak alkotmányától elvárják, másrészről felöleli azoknak az alkotmánygaranciáknak a minimumát, amelyek az alkotmányban kifejezett nagy társadalmi értékeknek a gyakorlatban való megvalósítását szavatolják. Az alkotmányosság követelményei, a demokratikus alkotmány tartalmában kifejezendő társadalmi értékek a következők: a népszuverenitás elve ${ }^{10}$ és a népképviselet, a hatalmi ágak szétválasztásának és egyensúlyának elve ${ }^{11}$, a törvények uralma ${ }^{12}$, a jogállam megvalósítása, egyenjogúság, jogegyenlőség, az emberi jogok garantálása. ${ }^{13} \mathrm{Az}$ emberi jogok alapja a másik ember iránti tisztelet elve. A kiindulási pontja, hogy bármely társadalom tagja, azaz minden ember erkölcsös és ésszerủen gondolkodó lény, akinek joga van ahhoz, hogy méltósággal kezeljék.

Az emberi jogok a Föld összes emberére kiterjednek, hiszen egyetemesek: vannak olyan nemzetek, társadalmak, országok, vagy meghatározott csoportok, amelyek kizárólag rájuk vonatkozó pluszjogokat élvezhetnek, de az emberi jogok a Föld összes emberét megilletik azért, mert élnek. Sokan az emberi jogokat meghallván a szólásszabadságra, a szabad véleménynyilvánításra vagy a vallás szabad megválasztására gondolnak, ez azonban meg sem közelíti a teljes és összes létező és bennünket megillető emberi jogot. Ezek a jogok is rendkívül fontosak, de az emberi jogok teljes skálája nagyon széles.

$10 \mathrm{Az}$ állami föhatalom forrása a nép, amely a közhatalomban közvetlenül (például népszavazás útján) és közvetve, a népképviseletek (önkormányzatok, Országgyülés) megválasztásával vesz részt.

11 A Montesquieu nevéhez füződő klasszikus tétel értelmében a törvényhozó, a végrehajtó és a bírói hatalmat az önkényuralom megakadályozása érdekében el kell választani egymástól. A kormányzás szervezetében kölcsönös függőség és ellenőrzés alakul ki, így a hatalmi ágak ellensúlyként és fékként müködnek a hatalmi koncentráció kizárása céljából.

12 Az állampolgárok magatartásának és az alkotmányos intézmények müködésének a kereteit az alkotmány és a törvények határozzák meg. A jogállamiság követelményéhez kapcsolható azoknak az alkotmányos garanciáknak, speciális intézményeknek a megteremtése is, amelyek fő funkciója az alkotmányosság és törvényesség védelme (például alkotmánybíráskodás, ombudsman, közigazgatási bíráskodás).

13 Az egyenjogúság vagy jogegyenlőség a jogalkotást és a jogalkalmazást egyaránt átfogó alkotmányos alapelv, amely az egyéneknek a közhatalommal fennálló viszonyában teremt azonos jogi helyzetet, és megtiltja a bármilyen alapú (nem, faj, vallás stb.) megkülönböztetést az emberi, illetve állampolgári jogok élvezetében. Az alkotmányos állam elismeri és szavatolja az emberek - nemzetközi normákban is rögzített - elidegeníthetetlen alapvető jogait. Chronowski Nóra - Drinóczi Tímea - Zeller Judit: Túl az alkotmányon... Az alkotmányvédelem elméleti és európai kontextusa, továbbá magyar gyakorlata 2010-ben, avagy felülvizsgálható-e az alkotmánymódosító törvény az Alkotmánybíróság által. Közjogi Szemle, 2010/4., 1-12. o. 
Korábbi tanulmányomban rendszereztem és összesítettem azokat a jogokat, amelyek e tárgykörbe tartoznak. ${ }^{14}$

E tanulmány keretén belül az általános személyiségi joggal szoros kapcsolatban álló emberi méltósághoz füződő jogot elemzem.

\section{Személyiségi, azaz emberi méltósághoz füződő jog}

A személyiségi vagy más néven személyhez füződő jogok az embernek mint természetes személynek és más jogi személyeknek szavatolják azt az integritást, amely védi a személyt a szükségtelen, illetéktelen beavatkozásoktól. ${ }^{15} \mathrm{~A}$ személyiségi jogok az ember jogállásának alapvető kifejezői közé tartoznak. ${ }^{16}$ A magyarországi szabályozás egyedülálló a tekintetben, hogy az általános személyiségi jogot tekintve nem csupán törvényi szinten, hanem alkotmánybírósági és bírósági határozatokban is szabályozták.

A személyiségi jogok érvényesülését és érvényesítését különféle hazai és nemzetközi szerződés is garantálja. Legfontosabb az Egyesült Nemzetek Szervezete által 1948. december 10-én elfogadott Emberi jogok egyetemes nyilatkozata ${ }^{17}$, amely közvetíti a szervezet álláspontját a minden embert megillető alapjogokról, amely minden csatlakozó államra nézve kötelező érvényü magatartási szabályokat fogalmaz meg. Kiemelt figyelmet érdemel még az Emberi jogok európai egyezménye ${ }^{18}$, amelynek főbb rendelkezéseit Magyarországon a korábbi alkotmány és a jelenleg hatályos alaptörvény is tételesen átvette.

Hazánkban már az 1959-es, első polgári törvénykönyv ${ }^{19}$ is megfogalmazott egy általános szabályt, az 1977-es novella pedig egyértelmüen az alkotmányjogtól függetlenül e jogcsoportvédelemröl rendelkezik. A jelenleg hatályos Ptk., vagyis a 2013. évi V. törvény, a 75. § (1) bekezdésben rendelkezik az általános szabályról: „, (a) személyhez füzödö jogokat mindenki köteles tisz-

\footnotetext{
14 Kovács István: Az emberkereskedelemhez szorosan kapcsolódó prostitúciós büncselekmények - különösképpen a gyermekprostitúció - áldozatai emberi jogainak hazai vonatkozásai. Polgári Szemle, 2014/3-6., 420-423. o.

15 Kiss Evelin - Nagy Viktor - Raus Csaba: Alkotmányosság a magánjogban. Scriptura, 2014/1., 250. o. 16 Sólyom László: A személyiségi jogok elmélete. KJK, Budapest, 1983, 10. o.

17 Az ENSZ Közgyülésének 217 A/(III) határozata (Emberi jogok egyetemes nyilatkozata). Hatályba lépett: 1948 . december 10 .

18 Emberi jogok európai egyezménye (1993. évi XXXI. törvény) az emberi jogok és az alapvető szabadságok védelméről szóló, Rómában, 1950. november 4-én kelt egyezmény és az ahhoz tartozó nyolc kiegészítő jegyzőkönyv kihirdetéséről. Hatályba lépett: 1993. április 7.

19 1959. évi IV. törvény a Polgári Törvénykönyvről. Hatályba lépett: 1959. október 1.
} 
teletben tartani. E jogok a törvény védelme alatt állnak. ${ }^{{ }^{20}}$ A jogcsoporton belül megkülönböztethetünk nevesített és törvényben nem nevesített személyiségi jogokat is. Ezen általános rendelkezés szerint mindkét típusú jogot törvényi védelem illeti. Szerteágazó sokféleségük miatt a személyiségi jogok mindegyikét nem lehet, és nem is célszerü jogszabályban katalogizálni.

Hatályos magánjogi kódexünk nevesíti a hátrányos megkülönböztetés tilalmát, a lelkiismereti szabadság garantálását, az emberi méltóság védelmét, a jó hírnév védelmét, a személyes szabadság jogellenes korlátozásának tilalmát, a testi épség és az egészség védelmét, a személyes adatok védelmét, a becsület védelmét, a névjogot (névviseléshez való jog), a magánlakáshoz való jogot, a magántitokhoz füződő jogot, a kegyeleti jogot és a képmás és hangfelvétel oltalmát. Ezeket a nevesített személyhez füződő jogokat az új polgári törvénykönyv is átvette. ${ }^{21}$

Az Alkotmánybíróság már egy igen korai határozatában foglalkozott az általános személyiségi jog alkotmányos szabályával, amelyet a Ptk.-hoz hasonlóan az alkotmány is az emberi méltósághoz való jogban fogalmaz meg. Ebben a határozatában az Alkotmánybíróság az emberi méltósághoz való jogot az úgynevezett ,általános személyiségi jog” egyik megfogalmazásának tekinti. Pontosabban az emberi méltósághoz való jogot az általános személyiségi joggal tartalmilag azonosként definiálja. ${ }^{22}$ A Földön élő összes embernek azonos szintủ méltósága van. Ez a méltóság a civilizáció alapjának tekintendő. Mindenkit ugyanaz a tisztelet, figyelem, törődés illet meg az állam, a jog és más ember részéröl. Ezt Hámori Antal így fogalmazza meg: „Az emberi méltóság alapja nem az értelem és a szabad akarat gyakorlásának aktuális képessége, hanem az emberi fajhoz tartozás ténye. Az Alkotmánybíróság egy másik, a halálbüntetés eltörléséröl rendelkezö határozatában pedig kifejtette, hogy a méltósághoz való jog másik funkciója az egyenlöség biztositása. Az egyenlö méltósághoz való jognak az élethez való joggal való egységében kell azt biztositania, hogy ne lehessen különbözöen értékes puszta életeket jogilag másként kezelni. Nincs az életre méltóbb és méltatlanabb. Hozzátehetjük, hogy az élethez való jogot és a méltóság fogalmát külön is használhatjuk ${ }^{23} \mathrm{Az}$ ember léte és létének minősége nem áll azonos etikai síkon. Nem a létminöség bizonyos kritériumok alapján meghatározott foka ad jogot a védelemhez

20 2013. évi V. törvény a Polgári Törvénykönyvről. Hatályba lépett: 2013. április 10.

21 Kiss Evelin - Nagy Viktor - Raus Csaba: i. m. 253. o.

22 8/1990. (IV. 23.) AB határozat.

23 23/1990. (X. 31.) AB határozat. 
és az élethez, hanem az emberlét maga. ${ }^{24}$ De vajon az egyén számára mit jelenthet az emberi méltósághoz való jog? Azt, hogy ténylegesen mit értünk e fogalmon, nehéz meghatározni, hiszen ez minden egyes embernél különböző értéket képvisel, az individuumtól függ, hogy számára a méltóság mit jelent.

A méltóság (dignitas) elöször az antik filozófiában jelent meg, mégpedig kettős jelentéssel. Egyrészt a közösségen belüli társadalmi, szociális pozíció jelöléseként, ami a rómaiak számára a személyiségnek a nyilvánosságban, a közéletben elfoglalt tekintélyét jelentette. A méltóság ezáltal nem mindenkit illetett meg, hanem csak azokat az embereket, akik a közösség, a nyilvánosság számára külön érdemeket szereztek. Ebben az értelemben a méltóság tehát az egyén teljesítményeként a társadalomban betöltött funkciójához kapcsolódott. Másrészt a méltóságot mint minden embernek a nem emberi teremtménytől való megkülönböztetéseként értelmezték, azaz ennyiben minden embert ugyanaz a méltóság illet meg. Ebben a felfogásban a méltóság elveszíthetetlen és változtathatatlan. ${ }^{25}$

Az ókor és középkor keresztény szerzőinek felfogása szerint az ember méltósága Isten kegyelmének igazolása, amely azon a tényen nyugszik, hogy az embert Isten a saját képmására teremtette. Ennek következtében minden embert azonos mértékben illet meg a méltóság. Más oldalról ez azt jelenti, hogy az ember méltóságát csak saját büne, vétke csorbíthatja, más nem. Ezáltal a méltóság az ember Istenhez való viszonyában tulajdonképpen a lelki üdvösség problémája. ${ }^{26}$

$\mathrm{Az}$ emberi méltóság új szemléletét a reneszánsz hozta. Pico della Mirandola az embert azoknak a lehetőségeknek az összességeként fogta fel, amelyek között a méltóságát megválaszthatja. Az embert kitüntető méltóság tehát tulajdonképpen az ő szabadságában ragadható meg. ${ }^{27}$

A XVIII. század filozófiájában, a felvilágosodás idején a méltóság szabadságkénti felfogását összekapcsolják a méltóság észben, értelemben való részesülés sztoikus felfogásával. Pascal és Pufendorf számára a méltóság az embernek az a szabadsága, hogy az értelemben elismertet válassza és tegye. Pufendorf a méltóságnak ezt a gondolatát összekapcsolja minden ember egyenlöségével, mivel minden embernek emberként megvan ez a képessége. Kant ezt a gondolatot azáltal zárta le, hogy az emberi méltóság fogalmával az

\footnotetext{
24 Hámori Antal: Állásfoglalás a haldokló, beteg ember életének és méltóságának védelmében. Magyar Kurír, 2009. február 11., 2. o.

25 Barcsi Tamás: Az emberi méltóság filozófiája. PhD-értekezés. Pécs, 2011, 21. o.

26 Uo. 30. o.

27 Uo. 35. o.
} 
emberi státust jelöljük, és arra a minőségre utalunk, amely miatt minden embernek kijár egy minimális szintü tisztelet. ${ }^{28}$

A mai emberkép-felfogást befolyásoló tényezők között tehát a filozófia, a kereszténység és a felvilágosodás ember- és méltóságfogalmai említendők meg. Ezek az eszmék és tradíciók, amelyek egyébként teljesen különböző értékelképzeléseket képviselnek, megegyeznek abban az általános alapgondolatban, hogy elismerik az ember olyan autonómiáját és önrendelkezését, amelyet az államnak nem szabad semmibe vennie.

Sólyom szerint az emberi méltósághoz való jognak két funkciója van. Egyrészt azt fejezi ki, hogy van egy abszolút határ, amelyen sem az állam, sem más emberek kényszerítő hatalma nem terjedhet túl, vagyis az autonómiának, az egyéni önrendelkezésnek egy mindenki más rendelkezése alól kivont magja, amelynél fogva - a klasszikus megfogalmazás szerint - az ember alany maradhat, és nem válik a jog számára eszközzé vagy tárggyá. Ezt fejezi ki egyébként az az Alkotmánybíróság által is osztott felfogás, hogy „az emberi méltósághoz való jog anyajog mindig újabb szabadságjogok forrása”, amelyek az önrendelkezés szféráját folyamatosan biztosítják az (állami) szabályozással szemben.

A méltósághoz való jognak ez a felfogása különbözteti meg az embert a jogi személyektöl, amelyek teljesen szabályozás alá vonhatók, nincs érinthetetlen lényegük. Ez az elvi különbség az ember és a jogi személy között, nem pedig az, hogy egyes jogok jellegüknél fogva csak emberhez füződhetnek. Az utóbbiak mintájára ugyanis mindig képezhetők analóg jogok a jogi személyek számára. A méltósághoz való jog másik funkciója az egyenlőség garantálása. A minden ember egyenlő méltósága történelmi vívmánya az egyenlő jogképességet jelentette. Ez egyben azt jelenti, hogy a méltóság oszthatatlan és redukálhatatlan, azaz az emberi státus minimális feltétele, hogy egyetlen embertől sem vehető el. Az egyenlő méltósághoz való jognak az élethez való joggal fennálló egységében kell azt szavatolnia, hogy ne lehessen különbözően értékes puszta életeket jogilag másként kezelni.

Az emberi méltóságban mindenki osztozik, aki ember, függetlenül attól, hogy mennyit valósított meg az emberi lehetőségből, és miért annyit. Az emberi méltósághoz való jog következtében nemcsak a halálban egyenlö mindenki: az életek egyenlőségét a méltóság garantálja. ${ }^{29}$ 
Az ember testi, értelmi és erkölcsi tulajdonságaival és teremtő képességeivel mint emberi lény kiemelkedik a többi élölény közül, és ezeknek a tulajdonságoknak és képességeknek az összessége adja az ember méltóságát, azaz saját ember voltának, fontosságának, jelentőségének, értékének felemelö tudatát.

\section{A prostituáltak orvosi igazolásának alkotmányellenessége, illetve az emberi méltóság mint alapjog megsértése}

Magyarországon jelenleg a prostitúció szabályozott keretek között, legálisan végezhető tevékenység. Ha a delikvensek a legkisebb szabályt megszegik, szabálysértési szankciókkal szembesülnek. A szabályozott keretek között zajló prostitúció modellje a prohibicionista (tiltó) modell gyengeségeit alapul véve, azt továbbfejlesztve dolgozta ki a saját stratégiáját. A rendszer képviselői abból indulnak ki, hogy a prostitúcióhoz kapcsolódó jelenség teljes tiltása - tekintettel arra, hogy azzal csak latenciába sodorjuk a történteket - nem vezethet eredményre. Nézeteik szerint a prostitúció elfogadott, de szükséges rossz jelenség, így megpróbálják azt - a hozzá kapcsolódó deviáns jelenségekkel együtt - különböző metódusokkal, szabályozásokkal, stratégiákkal keretek közé szorítani, így az üldöztetés következményét növelni.

Az üldöztetésen alapuló rendszer a jelenség szankcionálását teljes mértékben nem szünteti meg, csak lassítja, hiszen a büntetőjogilag tilalmazott magatartás megbüntetésére kizárólag akkor kerül sor, ha a keretet adó többi szabályozást - egészségügyi, szabálysértési, közigazgatási -, azaz a kontrollt adó szabályozást megszegik. A szabályok közé szorító modell elemeit az „orvosi (egészségügyi)”, és a „társadalmi” nézet tette lehetővé, erősítette meg. Az orvosi nézet a prostitúcióhoz kapcsolódó betegségek terjedésének kockázataival érvel, közegészségügyi szempontból, betegségek, járványok terjedésének és ezzel a többi ember életének, testi épségnek a védelmében szeretné szabályozottá nyilváníttatni a jelenséget. Az orvosi szemlélet a szifilisz felbukkanásának nyomán viszonylag korán megjelent: Betlen Anna megfogalmazásában már a XV. században felváltotta a „prostitúció-orvosság” típusú szemléletet a „prostitúció-ragály” megközelítés. A szemlélet éles ellentétben áll a korábban hivatkozott ,a nép által tisztelt intézmény” megközelítésével. ${ }^{30}$

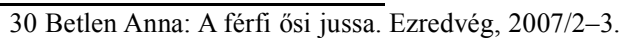


A XVIII. század uralkodó nézetét tartjuk a reglementációs modell első lépcsőjének, ami jogszabályosított formáját 1796-ban érte el.

A szabályozás elsődleges célja a túlságosan elterjedt nemi betegségek további terjedésének a meggátlása, másodlagos célja pedig a megbetegedett prostituált nők gyógykezelése volt. ${ }^{31}$ Petróczi és Kiss kutatásuk során feltárták Grosz Lajos azon szakirodalmát, amely az Orvosi Rendörség címü könyvében 1863-ban elsőként javasolta, hogy a kéjnők számának korlátozása érdekében szükséges, valamint rendszeres orvosi vizsgálatra kellene járniuk, legalább hetente két alkalommal. ${ }^{32}$ Grosz felfogását személy szerint én is támogatnám, tekintettel arra, hogy az a prevenciót szolgálta, a megelőzés egyik eszköze volt. Nem ítélte el, nem tartotta deviánsnak a prostituáltakat, az egészségük megőrzése érdekében orvosi szürést kínált számukra. Nézetei a későbbi abolicionista (áldozatszemléletü) modell szabályozásában is megjelentek.

Az alapkonstrukció viszont - sajnálatos módon - abból a felfogásból indul ki és azért tartja fontosnak a szabályozást, mert a prostituáltakat a betegség fö forrásaként kezeli. Betlen Anna müvében megállapította, hogy ez az uralkodó felfogás - a prostitúció a fertőző betegségek góca - csak az utóbbi kétszáz évben vált elfogadottá, annak társadalom-egészségügyi jelentőségü kérdésként való kezelése azonban sokkal távolabbi múltra tekintett vissza. ${ }^{33}$

Bodor a prostituáltakat a nemi betegségek terjesztésének fő forrásának nevezi. Múvében a prostitúciót a közegészségügy szempontjából figyelmet érdemlő problémának tekinti. A gonorrheás megbetegedések terjesztésében a prostituáltakkal folytatott nemi érintkezés következményét jelentős tényezöként említi meg. ${ }^{34}$ Hontvári Emil szintén annak káros hatásairól beszél. Elsődlegesen egészségügyi szempontból jelentkező káros hatásait említi, amelyek a fertőző nemi betegségek terjedését segítik elő. A modell alapjául szolgáló szabályozás kidolgozására javaslatot is tett. ${ }^{35}$

\footnotetext{
31 Schreiber Emil: A prostitució. Pátria Irodalmi Vállalat és Nyomdai R.T., Budapest, 1917

32 Petróczi Gabriella: Megélhetési perspektíva a prostitúcióban. Rendészeti Szemle, 2007/3., 80-96. o.; Kiss Bernadett: A közterületi és közrendbe ütköző deviáns magatartások rendészeti szabályozása a XIX-XX. század fordulóján. In: Gaál Gyula - Hautzinger Zoltán (szerk.): Tanulmányok a „Rendészet kultúrája - kulturált rendészet” című tudományos konferenciáról. Pécs, 2009, 135-149. o. [Pécsi Határör Tudományos Közlemények X.]

33 ,Érdekes ugyanakkor megfigyelni, hogy ez a társadalmi szintü »baj« eleinte elsösorban egészségügyi jelleggel bir: századokon át a prostitúciót mint az össztársadalom (értsd: a férfiak) egészségi problémáját tárgyalták." Betlen Anna: i. m.

34 Bodor Endre - Szücs János: A prostitúció helyzete a fővárosban. Belügyi Szemle, 1964/6.

35 „A prostitúció kérdésének napirendre tüzését - véleményem szerint-annak egészségügyi káros hatása is indokolja. ” Hontvári Emil: A prostitúció elleni harc néhány kérdéséről. Belügyi Szemle, 1965/8., 65-69. o.
} 


\section{HÍRES BÜNÜGYEK, TANULSÁGOS NYOMOZÁSOK}

Szabályozási javaslatuk alátámasztására Diószeghy és Hontvári a kormánytól várt megoldást. Diószeghy egyebek között kiemelte, hogy a kormánynak feltétlenül segítenie kell, mert a titkos prostitúció folyamatosan terjed, és hiába törekszik a rendőrség a megtervezett akciókkal megakadályozni a folyamatot, az nem sikerül. Elméletét azzal próbálta erősíteni, hogy a nemi betegségek terjedésének az utókorra is hatása lesz, így a fajfenntartás kétségessé válhat. ${ }^{36}$ Hartay a válogatás nélkül létesített nemi kapcsolatokat tartotta a nemi betegségek terjesztése forrásának. ${ }^{37}$ Nézetével nem értek egyet. Nem lehet általánosítani és kizárólag a prostituáltak személyére redukálni azokat a kapcsolatokat, amelyek válogatás nélkül létesítődnek. Magánszemélyek százai, ezrei élnek nyitott hetero-, homo- és biszexuális kapcsolatban, egyedülállóként folyton váltogatják a partnereiket. Nagyon jó példa erre a szifilisz elterjedése. Miután a szifilisz gyógyítása a penicillin felfedezése után megoldottnak látszott, az 1960-as években szinte megszüntnek tekintették. Ez után azonban - teljes meglepetésként - a szifiliszes fertözéses esetek újabb átmeneti szaporodását észlelték, a hatásos terápia ellenére elsősorban társadalmi okok és a szexuális magatartás változásai befolyásolták. ${ }^{38}$ Magyarországon a statisztikai adatok szerint évente több mint ötezer új nemi betegséggel érintett személyt fedeznek fel. ${ }^{39}$

Marschalkó Tamás az üzletszerü kéjelgőket a venerikus bántalmak legföbb terjesztőjének tartja, és a reglementációs szabályozást gondolja az egyetlen járható útnak, a legnagyobb befolyásra és jelentőségre tekintettel. ${ }^{40}$ Bódis Enikö kifejti, hogy e nézetek miatt a társadalom úgy tekint a szexmunkásokra, mint a betegség hordozóira, a köz szégyenére vagy áldozatára, nem mint önálló, racionális megfontolásokkal bíró ágensekre. ${ }^{41}$

36 ,A kormánynak feltétlenül kell valamit tenni ebben a kérdésben, mert az így semmiféleképpen sem maradhat, elvégre nem lehet összetett kezekkel, tanácstalanul és vállvonogatással nézni ezer meg ezer egészséges fiatalembernek a megfertözését, ami végeredményben az utódokra is kihat." Diószeghy Miklós: Veszedelmesen terjed a prostitúció. Budapesti Negyed, 2010. ösz

37 Hartay Henrik: A prostitúció büntetőjogi üldözése. Hozzászólás dr. Heller Farkas Tamás A prostitúció időszerü kérdései címü cikkéhez. Belügyi Szemle, 1965/9., 55-62. o.

38 Kapronczay Károly: A dermatológia Magyarországon. Budapest, 1922

39 Kornya László: Humán papillomavírus a XXI. század kihívása. Doktori értekezés, Pécs, 2011, 7. o.

40 Marschalkó Tamás: A venerikus betegségek terjedése Budapesten és a prostitutio. Előadás a budapesti királyi orvos egyesület 1895. III. 2-án tartott rendes ülésén. Orvosi Hetilap, 1895, 33. o.

41 Bódis Enikő: Prostituált narratívák. In: „Adás - Vétel”. Konferencia a prostitúcióról. Narratívák/szemelvények a Magyar Szociológiai Társaság és az Országos Kriminológiai Intézet közös szervezésében, 2011. szeptember 15-én, az OKRI-ban elhangzott konferencia-előadásokból. OKRI, Budapest, 2011, 17. o. 
Az előbbiek következtében jöhetett létre a 41/1999. (IX. 8.) EüM rendelet melléklete, a prostituáltaknak kiadandó orvosi igazolásról szóló 41/1999. (IX. 8.) EüM rendelet 1. § (4) bekezdése is. ${ }^{42}$ A szabályozás után annak alkotmányellenességéról az Alkotmánybíróságnak kellett döntenie, tekintettel arra, hogy az súlyos alapjogokat és nemzetközi szerződéseket sért.

Az Alkotmánybíróság az 1955. évi XXXIV. törvényerejü rendelettel kihirdetett, az emberkereskedés és mások prostitúciója kihasználásának elnyomása tárgyában, New Yorkban, 1950. március 21-én kelt nemzetközi egyezménybe ütközönek találta a prostituáltaknak kiadandó orvosi igazolást, mert az egyfajta okmánynak számít, és szerepel benne, hogy birtokosa prostituált, ezért a vonatkozó rendelet igazolványmintát tartalmazó mellékletét 2011. december 31-i hatállyal megsemmisítette.

A testület az 1/2011. (I. 14.) számú határozatában azért semmisítette meg év végi hatállyal a mellékletet, hogy a jogalkotónak megfelelö idő álljon a rendelkezésére ahhoz, hogy az alkotmányellenes helyzet megszüntetéséhez szükséges feladatának eleget tehessen. A mellékletben szerepel „a prostituáltak részére kiadandó orvosi igazolás...” kifejezés, aminek alapján a dokumentum birtokosának foglalkozása azonosítható. A megsemmisítésről döntő szerv nem az orvosi vizsgálat szükségességét vizsgálta - erre Kovács Péter alkotmánybíró párhuzamos indoklásában rá is mutatott, hogy más nemzetközi szerződések, illetve európai uniós jogi kötelezettségek írják elő -, hanem az erről kiállítandó okmányt találta nemzetközi szerződésbe ütközőnek.

Az Alkotmánybíróság leszögezte, hogy a törvényhozó a jellemzően nemi úton terjedő betegségekkel leginkább veszélyeztetettek egészségvédelmét, közegészségügyi szempontok érvényesülését is célozni kívánja. A vizsgált szabályozás - tehát a kötelező orvosi vizsgálat előírása - összefügg az alkotmányból eredő állami kötelezettséggel, az ilyen jellegü megbetegedések elleni védelem elősegítésével, egészségügyi intézményhálózat működtetésével, az orvosi ellátás megszervezésével. Ennek folyamán azonban a jogalkotónak a nemzetközi kötelezettségvállalásokra és az alkotmány rendelkezéseire figyelemmel kell eljárnia, amelynek során gondoskodnia kell arról, hogy a szabályozásokkal érintettek alapvető emberi jogai, az emberi méltósághoz füződő és információs önrendelkezési jogai ne sérüljenek.

Az Alkotmánybíróság arra mutatott rá, hogy a Magyarországon 1955-ben kihirdetett 1950-es New York-i egyezmény tiltja a prostituáltak nyilvántartásba vételét vagy igazolvánnyal ellátását. Az Alkotmánybíróság szerint a vizs-

42 A prostituáltak részére kiadandó orvosi igazolásról szóló 41/1999. (IX. 8.) EüM rendelet. 
gált rendelkezés külön igazolványt ad az efféle tevékenységet végzőknek, $\mathrm{s}$ maga a testület is megjegyzi, hogy amint a köznyelv mondja: „bárcával” látja el őket. A testület szerint ez az érintettek stigmatizálása, és az emberi méltósághoz való jogukat sértő vagy azt előidéző jogi szabályozás.

A nemi betegségek hordozása miatt szabályozást igénylő modell és nézeteik megcáfolására a következőket kívánom részletezni: Cunningham és Christensen kutatásai rávilágítottak arra, széles körü orvosi dokumentációk bizonyítják, hogy a kliens fertőzi meg a prostituáltat HIV-vel hüvelyi és végbéli közösülés útján. A nemi erőszak és a kondom nélküli szexre való kényszerítés - vagy rábeszélés több pénz ígéretével - a lányok közötti fertőzés elsődleges forrásának tekintendö. Raymond, Hughes és Gomez tanulmánya statisztikai adatokkal bizonyította a felvetéseket: egy a prostitúcióról készült tanulmány szerint a nők 47 százaléka állította azt, hogy a férfiak elvárják a kondom nélküli szexet, 73 százalékuk szerint a férfiak több pénzt ajánlottak a kondom nélküli szexért, és 45 százalékuk mondta, hogy a férfiak erőszakossá váltak, ha a nő ragaszkodott a kondomhasználatához. ${ }^{43}$

Betlen Anna is külön kiemeli azt, hogy egész könyveket írnak tele azokkal a testi bajokkal, amelyek egyrészt a nem rendeltetésszerü szex (például anális), másrészt az erőszak (nemi erőszak, ütlegelések, különféle eszközök használata stb.), harmadrészt az iszonyat elviselését könnyítő szerhasználat következtében lépnek fel a prostituáltaknál. ${ }^{44}$ További felmérések azt is alátámasztják, hogy a hivatásos prostituáltak között - minden bizonnyal azért, mert következetesebben ragaszkodnak óvszer használatához - lényegesebben alacsonyabb a vírusfertőzöttek aránya, mint a titkos prostituáltak között. Ez azért is lényeges, mert a női drogfüggő vírushordozó férfi partnereinek infekciós rátája 50 százalék. ${ }^{45}$

Ugyanakkor a védekezéshez való ragaszkodás kétértelmű: Fehér Lenkenézeteim alátámasztására - kifejti, hogy a prostituáltak fokozott egészségi kockázatnak vannak kitéve. A szexuális úton átvihető betegségek igen elterjedtek a körükben. Kevés prostituált teheti meg, hogy visszautasítson egy klienst, vagy az úgynevezett biztonságos szex feltételeihez ragaszkodjék. A HIV és az AIDS rizikófaktora is óriási. ${ }^{46}$

\footnotetext{
43 Leonard Cler-Cunningham - Christine Christensen: Violence against women in Vancouver's streetlevel sex trade and the police response. PACE Society, Vancouver, 2001; Janice Raymond - Donna Hughes - Carol Gomez: Sex Trafficking of Women in the United States: Links between International and Domestic Sex Industries. Coalition against Trafficking in Women, Massachusetts, 2001 44 Betlen Anna: Szabadon vagy önként. Élet és Irodalom, 2009/29. 45 Nagy Gábor: Narkománia - prostitúció - AIDS. Belügyi Szemle, 1990/7., 23-27. o. 46 Fehér Lenke: A prostitúció valósága és a szabályozási modellek. Belügyi Szemle, 1997/4., 14-27. o.
} 
Értetlenül állok azon nézetek elött, amelyek a prostituáltakat mint a betegség fö hordozóit elkövetőnek tekintik. Vajon a szabályozás alapját adó vizsgálatok miért a prostituált nők szürésére korlátozódnak, amikor a földrajzi és nemek szerinti terjedésre vonatkozó legfrissebb adatok szerint elsősorban a férfiak felelősek az AIDS-fertőzésért? Ezt kísérleteivel Hynes és Raymond is alátámasztotta. ${ }^{47}$

Az állami szabályozás, amely elméletileg a prostituáltakat védené, miért csak a prostituáltakra vonatkozik? Miért csak az ő kötelező szürővizsgálatukat írja elő? Ha valóban az állami igény érvényesítése volna a cél - és nem a prostituáltak boszorkányüldözése -, akkor a prostituáltakat látogató férfiakat is kötelezni kellene egészségügyi szürésen való részvételre, ellenörzésre és igazolás beszerzésére. Nézetemet Janice Raymond is alátámasztotta. ${ }^{48} \mathrm{~A}$ statisztikai számokkal és kutatásokkal igazolt prostituáltüldözés - pusztán a szabályozás alátámasztására - elítélendő, egyoldalú és személyiségsértő.

Egy társadalomban mindenki egyenértékü, nem lehet megkülönböztetés és kirekesztés. A prostituáltakat megbélyegző és kizárólag őket orvosi vizsgálatra kötelező szemlélet jogokat sért, egyoldalú, éppen ezért szabályozás alapja szintén nem lehet. A korábban hivatkozott jogszabályi rendelkezés és szabályozás szükségességénél vizsgálni kell a legnagyobb szerepet játszó közvetett és közvetlen hatásokat, fel kell tárni a szabályozás pozitív és negatív hatásait egyaránt, így nélkülözhetetlen szempont, hogy a prostituáltak szemszögéből is lássuk az egészségügyi szabályozás mikéntjét. Nagyon fontos az is, hogy azok a nők, akik valamilyen - közvetlen, közvetett - kapcsolatba hozhatók a prostitúcióval, nagyon súlyos pszichés és egészségi károsodást szenvednek el. Gondoljunk csak azokra, akik mondjuk a kliensek, szeretteik, családtagjaik, nevelőik által erőszak áldozatává válnak, a testük használati eszköz lesz, és nincs remény arra, hogy előbb-utóbb ebből meggyógyuljanak, leginkább a miatt a tény miatt, hogy egyáltalán nem vagy alig lehet őket meggyógyítani. Betlen Anna úgy fogalmaz, hogy sem egyénenként, sem pedig tömegesen nem lenne erre képes egy szabályozás. ${ }^{49}$

Gondoljunk abba bele, hogy a regeneráció hiánya, az alvásnélküliség, a nem megfelelő táplálkozás, a higiénia hiánya, a szadizmus, a brutalitás állandó jelenléte mind-mind hozzájárul a prostitúcióban részt vevő nők számos

\footnotetext{
47 H. Patricia Hynes - Janice G. Raymond: "Putin Harm's Way: The Health Consequences of Sex Trafficking in the United States.” In: Jael Silliman - Anannya Bhattacharjee (eds.): Policing the National Body: Race, Gender, and Criminalization. South End Press, Boston, 2002, pp. 197-229. 48 Janice Raymond - Donna Hughes - Carol Gomez: i. m. 49 „Adás - Vétel”... i. m.
} 
egészségi és környezeti ártalmához. Gyakran előforduló betegségek a tbc, a vérszegénység, a hepatitis $B$, valamint a nemi úton terjedö betegségek, egyebek között a krónikus szifilisz, a gonorrhoea, a herpesz, nőgyógyászati betegségek, például a medence-, a méh-, a hüvelygyulladás és -irritáció, hüvelyi vérzés, amelyet érzékenység és a túl sok partner okoz, méhnyakrák; fizikai sérülések, például vágások, zúzódások, horzsolások, mozgásszervi sérülések, szélsőséges esetekben csonkolások és gyilkosságok. ${ }^{50}$

Forrai Judit szintén hasonló megbetegedéseket és hozzájuk kapcsolódó tüneteket mutatott ki felmérései alapján: a felvetődő problémák közül jellemzők a vegetatív és szomatikus betegségek és azok tünetei. A felvetődő tünetek és betegségek jól mutatják a sérülékenységüket. A külföldre csábított, majd prostituáltként dolgoztatott nők 59 százalékát addigi életükben megeröszakolták, az érkezésükig már 95 százalékuk került ilyen állapotba. ${ }^{51}$ Továbbá arra is kiemelt figyelmet kell fordítani, hogy a prostituáltak lelki és fizikai fájdalmaik enyhítésére milyen élvezeti cikkeket használnak. A szexuális szolgáltatók rizikómagatartása nemcsak a szexuális úton fertőző betegségek terjedését jelenti, hanem az üzleti életet kísérő, azt elviselni segítő egyéb szerek: a dohány, az alkohol, a drog használatát is. Epidemiológiai felmérések igazolják a rizikómagatartást kiváltó multikauzális tényezők hosszú sorát: szociális, pszichés és közegészségügyi faktorokat. ${ }^{52}$

További bizonyíték annak a nézetemnek az alátámasztására, miszerint az or-

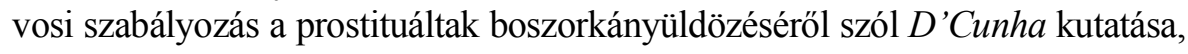
amely kimondta, hogy kormányok az évek folyamán közegészségügyi intézkedésként igazolták a prostitúcióban lévő nők társadalmi és törvényi kontrollját, míg könnyed érdektelenséget mutattak a másfajta egészségi problémái iránt. ${ }^{53}$

A szabályozás kérdését nem lehet egyoldalúan kezelni, a közvetett és közvetlen elö- és utóhatását is minden szempontból vizsgálni kell, ezért sem lehet a megoldás alapja.

Mindamellett nagyon fontos az a tény is, hogy a fertőzéssel kapcsolatba kerülők (orvosok, ápolók stb.) is kockázatot vállalnak a vizsgálatok elvégzé-

\footnotetext{
50 Jean D'Cunha: Legalizing Prostitution: In Search of Alternative from a Gender \& Rights Perspective. In: Gunilla Ekberg: Seminar on the Effects of Legalisation of Prostitution Activities. Stockholm 5-6 November, 2002, pp. 28-46. http://naring.regeringen.se/fragor/jamstalldhet/pdf/N3006.pdf. Magyarul Szeminárium a prostitúció törvényesítésének hatásairól. Kritikai elemzés. Prostitúció Nélküli Magyarországért Mozgalom, Budapest, 2014. május 24. prostitucio.hu/stockholm.2002.hu.pdf

51 Forrai Judit: Prostitúció és globalizáció. Eszmélet, 2010, 145-154.

52 Forrai Judit: Prostitúció és szociális munka. Civil Szemle, 2007/11., 67. o.

53 Jean D'Cunha: The Legalization of prostitution. A sociological inquiry into the laws relating to prostitution in India and the West. Wordmakers for the Christian Institute for the Study of Religion and Society, 1991
} 
sekor. Véleményem szerint rájuk is ki kellene terjeszteni az egészségügyi szürést, vagy legalább meg kellene teremteni a megelőzéshez szükséges megfelelö higiéniai környezetet. Ahogy a bünözés nagy része is latens, vannak olyan regisztrálatlan és esetleg feketén müködő orvosi centrumok, ahol a hatályos jogi szabályozás nem érvényesül. Az ilyen helyeket szoros felügyelet és kontroll alá kell venni, és ellenőrizni kell a hatályos szabályozás végrehajtását. A háziorvosi, házi gyermekorvosi és fogorvosi tevékenységről szóló 4/2000. (II. 25.) EüM rendelet, valamint a fertőző betegségek és a járványok megelözése érdekében szükséges járványügyi intézkedésekről szóló 18/1998. (VI. 3.) NM rendelet elöírja az orvosi tevékenység és vizsgálatok részletes szabályait. Így érvényesülhet az orvosok, ápolók és az általuk kezeltek szürése is.

\section{Konklúzió}

Az alapvető jogok garantálása az uniós jog egyik alapköve. Ebből adódóan az emberi méltóság védelme a közös európai jogrend egyik alapja. Az európai szerződések hosszú időn át nem foglalták magukban e jogok írásos jegyzékét, csupán az emberi jogok és alapvető szabadságok védelméről szóló európai egyezményre hivatkoztak.

A szerződések az uniós jog általános elveiként utaltak a tagállamok közös alkotmányos hagyományaiból következő alapvető jogokra. Emellett ítélkezési gyakorlata révén az Európai Bíróság szintén nagyban hozzájárult az alapvető jogok fejlődéséhez és tiszteletben tartásához.

McCrudden szerint az emberi méltóság fogalma jogrendszerenként változik, olykor még egy adott jogrendszeren belül is mást és mást jelenthet, de ettől még az emberi méltóságnak kiemelt jelentősége van az emberi jogokat érintő ügyek eldöntésekor. ${ }^{54}$

Az emberi méltóság egyik funkciója az autonómia, hiszen az emberi méltóság , az egyéni önrendelkezésnek egy mindenki más rendelkezése alól kivont magja, amelynél fogva [...] az ember alany maradhat, és nem válik eszközzé vagy tárggyá" [8/1990. (IV. 23.) AB határozat]. A jog másik funkciója az egyenlőség szavatolása azáltal, hogy a méltóság mindenkit egyenlően megillet.

Minden államnak érdeke, hogy a területén élő állampolgároknak az alapvető és emberi létéből adódó jogaira és azok érvényesülésére garanciát vállaljon.

54 Christopher McCrudden: Human Dignity and Judicial Interpretation of Human Rights. European Journal of International Law, vol. 19, no. 4, 2008, pp. 655-724. 


\section{HÍRES BÜNÜGYEK, TANULSÁGOS NYOMOZÁSOK}

\section{IRODALOM}

Barcsi Tamás: Az emberi méltóság filozófiája. PhD-értekezés. Pécs, 2011

Barna Attila - Horváth Attila - Máthé Gábor - Tóth Zoltán József: Magyar állam- és jogtörténet. Nemzeti Közszolgálati Egyetem, Budapest, 2014

Betlen Anna: A férfi ősi jussa. Ezredvég, 2007/2-3.

Betlen Anna: Szabadon vagy önként. Élet és Irodalom, 2009/29.

Bódis Enikő: Prostituált narratívák. In: „Adás - Vétel”. Konferencia a prostitúcióról. Narratívák/szemelvények a Magyar Szociológiai Társaság és az Országos Kriminológiai Intézet közös szervezésében, 2011. szeptember 15-én, az OKRI-ban elhangzott konferenciaelőadásokból. OKRI, Budapest, 2011

Bodor Endre - Szücs János: A prostitúció helyzete a fővárosban. Belügyi Szemle, 1964/6.

Chronowski Nóra - Drinóczi Tímea - Zeller Judit: Túl az alkotmányon... Az alkotmányvédelem elméleti és európai kontextusa, továbbá magyar gyakorlata 2010-ben, avagy felülvizsgálható-e az alkotmánymódosító törvény az Alkotmánybíróság által. Közjogi Szemle, 2010/4.

Cler-Cunningham, Leonard - Christensen, Christine: Violence against women in Vancouver's street-level sex trade and the police response. PACE Society, Vancouver, 2001

Csink Lóránt: Alkotmányjog. Novissima Kiadó, Budapest, 2010

D'Cunha, Jean: The Legalization of prostitution. A sociological inquiry into the laws relating to prostitution in India and the West. Wordmakers for the Christian Institute for the Study of Religion and Society, 1991

D'Cunha Jean: Legalizing Prostitution: In Search of Alternative from a Gender \& Rights Perspective. In: Gunilla Ekberg: Seminar on the Effects of Legalisation of Prostitution Activities. Stockholm 5-6 November, 2002, pp. 28-46. http://naring.regeringen.se/fragor/jamstalldhet/pdf/N3006.pdf. Magyarul Szeminárium a prostitúció törvényesítésének hatásairól. Kritikai elemzés. Prostitúció Nélküli Magyarországért Mozgalom, Budapest, 2014. május 24. prostitucio.hu/stockholm.2002.hu.pdf

Diószeghy Miklós: Veszedelmesen terjed a prostitúció. Budapesti Negyed, 2010. ősz

Fehér Lenke: A prostitúció valósága és a szabályozási modellek. Belügyi Szemle, 1997/4.

Forrai Judit: Prostitúció és szociális munka. Civil Szemle, 2007/11.

Forrai Judit: Prostitúció és globalizáció. Eszmélet, 2010

Fülöp Sándor: A jövő nemzedékek országgyülési biztosának javaslatai - az új alkotmány koncepciójának kidolgozásához. Budapest, 2010. szeptember 30. $\mathrm{http}: / /$ www.jno.hu/hu/?\&menu=aktualis\&doc=alkotmany-1001

Hámori Antal: Állásfoglalás a haldokló, beteg ember életének és méltóságának védelmében. Magyar Kurír, 2009. február 11.

Hartay Henrik: A prostitúció büntetőjogi üldözése. Hozzászólás dr. Heller Farkas Tamás A prostitúció időszerü kérdései című cikkéhez. Belügyi Szemle, 1965/9.

Hontvári Emil: A prostitúció elleni harc néhány kérdéséről. Belügyi Szemle, 1965/8.

Hynes, H. Patricia - Raymond, Janice G.: "Putin Harm's Way: The Health Consequences of Sex Trafficking in the United States." In: Silliman, Jael - Bhattacharjee, Anannya (eds.): 
Policing the National Body: Race, Gender, and Criminalization. South End Press, Boston, 2002

Kapronczay Károly: A dermatológia Magyarországon. Budapest, 1922

Kiss Bernadett: A közterületi és közrendbe ütköző deviáns magatartások rendészeti szabályozása a XIX-XX. század fordulóján. In: Gaál Gyula - Hautzinger Zoltán (szerk.): Tanulmányok a „Rendészet kultúrája - kulturált rendészet” címü tudományos konferenciáról. Pécs, 2009, 135-149. o. [Pécsi Határőr Tudományos Közlemények X.]

Kiss Evelin - Nagy Viktor - Raus Csaba: Alkotmányosság a magánjogban. Scriptura, 2014/1. Kornya László: Humán papillomavírus a XXI. század kihívása. Doktori értekezés, Pécs, 2011 Kovács István: Az emberkereskedelemhez szorosan kapcsolódó prostitúciós bủncselekmények - különösképpen a gyermekprostitúció - áldozatai emberi jogainak hazai vonatkozásai. Polgári Szemle, 2014/3-6.

Marschalkó Tamás: A venerikus betegségek terjedése Budapesten és a prostitutio. Előadás a budapesti királyi orvos egyesület 1895. III. 2-án tartott rendes ülésén. Orvosi Hetilap, 1895

McCrudden, Christopher: Human Dignity and Judicial Interpretation of Human Rights. European Journal of International Law, vol. 19, no. 4, ,2008.

Nagy Gábor: Narkománia - prostitúció - AIDS. Belügyi Szemle, 1990/7.

Papp Iván: Jogi- és államigazgatási ismeretek. FVM Képzési és Szaktanácsadási Intézet, Nyíregyháza, 2004

Petróczi Gabriella: Megélhetési perspektíva a prostitúcióban. Rendészeti Szemle, 2007/3.

Raymond, Janice - Hughes, Donna - Gomez, Carol: Sex Trafficking of Women in the United States: Links between International and Domestic Sex Industries. Coalition against Trafficking in Women, Massachusetts, 2001

Schreiber Emil: A prostitució. Pátria Irodalmi Vállalat és Nyomdai R.T., Budapest, 1917

Sólyom László: A személyiségi jogok elmélete. KJK, Budapest, 1983

\section{JOGSZABÁLYOK}

1949. évi XX. törvény

1959. évi IV. törvény

1989. évi XVII. törvény

1989. évi XXXI. törvény

2013. évi V. törvény

A prostituáltak részére kiadandó orvosi igazolásról szóló 41/1999. (IX. 8.) EüM rendelet 8/1990. (IV. 23.) AB határozat

A háziorvosi, házi gyermekorvosi és fogorvosi tevékenységről szóló 4/2000. (II. 25.) EüM rendelet

A fertőző betegségek és a járványok megelőzése érdekében szükséges járványügyi intézkedésekről szóló 18/1998. (VI. 3.) NM rendelet 